\title{
Household Perceptions, Willingness to Pay, Benefit Package Preferences, Health System Readiness for National Health Insurance Scheme in Southern Nigeria
}

\section{Ishola Babatunde Omotowo1*, Uchechukwu Enuma Ezeoke1, Ikechukwu Emmanuel Obi1, Benjamin S. Chudi Uzochukwu' ${ }^{1}$, Chike Chuka Agunwa ${ }^{1}$, Christopher Bismarck Eke², Chinedu Arthur Idoko', Ancilla Kate Umeobieri1}

${ }^{1}$ Department of Community Medicine, College of Medicine, University of Nigeria, Enugu Campus, Enugu, Nigeria ${ }^{2}$ Department of Paediatrics, College of Medicine, University of Nigeria, Enugu Campus, Enugu, Nigeria Email: *babatundeomotowo@yahoo.com

How to cite this paper: Omotowo, I.B., Ezeoke, U.E., Obi, I.E., Uzochukwu, B.S.C., Agunwa, C.C., Eke, C.B., Idoko, C.A. and Umeobieri, A.K. (2016) Household Perceptions, Willingness to Pay, Benefit Package Preferences, Health System Readiness for National Health Insurance Scheme in Southern Nigeria. Health, 8, 1630-1644.

http://dx.doi.org/10.4236/health.2016.814159

Received: August 30, 2016

Accepted: November 27, 2016

Published: November 30, 2016

Copyright $\odot 2016$ by authors and Scientific Research Publishing Inc.

This work is licensed under the Creative Commons Attribution International License (CC BY 4.0).

http://creativecommons.org/licenses/by/4.0/

\begin{abstract}
Introduction: Several Nigerians are completely denied access to adequate health care because of cultural, temporal and financial factors with inequity. Objectives: To ascertain the household perceptions, willingness to pay, benefit package preferences, and health systems readiness for Insurance Scheme. Methods: A cross-sectional study of 400 heads of households and 43 health workers in Enugu, Southern Nigeria. Results: Awareness of NHIS among the heads of household was $56.8 \%$, while it was $86 \%$ among the health workers. Awareness of NHIS among heads of households was significantly associated to both educational level $\left(\mathrm{X}^{2}=16.083, \mathrm{P}=0.001\right)$, and occupation $\left(\mathrm{X}^{2}=5.694, \mathrm{P}=0.017\right)$. More males $(61.6 \%)$ had correct perceptions of NHIS compared to females (58.6\%), but not statistically significant $\left(\mathrm{X}^{2}=0.336, \mathrm{P}=0.562\right)$. Majority of households respondents $89 \%$ are willing to pay for NHIS. Willingness to pay was significantly associated to occupation $\left(\mathrm{X}^{2}=5.169, \mathrm{df}=1, \mathrm{P}=0.023\right)$, but willingness to pay mandatory $5 \%$ premium was not significantly associated to occupation $\left(\mathrm{X}^{2}=0.884, \mathrm{P}=347\right)$. Only $11.6 \%$ of the health facilities are enlisted as providers in the scheme. Conclusion: Willingness to pay was high, but majority are not ready to pay $5 \%$ premium of their earnings. Awareness creation programmes should be improved for the public, and more health facilities enlisted for wider coverage.
\end{abstract}

\section{Keywords}

Perceptions, Willingness to Pay, Health Insurance, Nigeria 


\section{Introduction}

Globally an estimated 13 billion people lack access to effective and affordable health care, and annually additional 150 million people in 44 million households face financial catastrophe as a result of paying directly for health care. Also, about 100 million people are pushed into poverty due to the need to pay for health services [1]. The availability of the necessary finance remains a formidable obstacle to further progress in many developing countries. Also, the economic growth rate has been much lower than the rate of population growth. For so many reasons, the health sector has often found itself with a budget which has declined substantially in real terms. Poverty and poor access to health care services are major development problems in Africa particularly in Nigeria [2].

Health insurance is attracting more and more attention in low and middle income countries as a means for improving health care utilization and protecting households against impoverishment from out-of-pocket expenditures [3] [4]. Also, World Health Organization (WHO) considers health insurance a promising means of achieving universal health care coverage [5]. Social health insurance scheme is one of the major sources of health care financing used by virtually all developed countries and some developing countries [5]. African governments focused on direct payment, after most countries started to move more towards facilitating health insurance schemes. Africans live, on average, 14 years less than the average world citizen, and 21 years less than the average European [6], so efficient healthcare financing is very essential for improvements in the health indicators. Direct payment at point of use is the least optimal way of financing healthcare. According to WHO, two years after Burundi introduced user fees for healthcare in 2002; four out of five in that country were either in debt or had sold assets to pay for healthcare [6]. In Rwanda, 91\% of the population belongs to one of the three health insurance schemes, while only, $30 \%$ of private health expenditure was out-of-pocket in Botswana [6]. Health insurance coverage is increasing in Ghana, Tanzania and South Africa. The coverage increased from $8.5 \%$ in 2008 to $18.1 \%$ in 2011, and 32\% in 2010 to 35\% in 2012 in Tanzania and Ghana respectively [7] [8]. Health insurance is among the solutions promoted in developing countries since the 1990s to improve access to health care services because it avoids direct payment of fees by patients and spreads the financial risk among all the insured [9] [10].

Heath Insurance Schemes have been in operation in Germany since 1883, Norway 1909, Sweden 1910, and Russia 1911. In United Kingdom, compulsory Health Insurance became law in 1911 [11] [12]. Today, virtually all countries in the developed world and several in the developing world e.g. India and Indonesia use health insurance as one of the viable ways of financing heath care. In Nigeria, the need for the health insurance as one of the necessary means of health care financing was recognized over 50 years ago. The federal government, seeking a panacea for this challenge, launched the National Health Insurance Scheme (NHIS) on October $15^{\text {th }} 1997$, while the enabling law was signed in May 1999. However, actual implementation commenced in 2002, while the scheme was re-launched on June 6, 2006 in Abuja by President Olusegun Obansajo [11] [12] [13]. The National Health Insurance coverage has been on the in- 
crease over the last decade; from less than 150,000 lives in 2004 to about 5 million (3\% of the population) in 2014, though the presidential mandate to ensure universal coverage of Nigerians by 2015 was not achieved [14] [15]. There was resistance in the onset of the scheme, in 2013, 98\% of all Nigerian federal employees and two million additional private sector workers enrolled with NHIS [16] [17].

The Nigeria Health sector has been chronically under-funded despite increasing need for health services. This has resulted in a very sharp drop in health indices with an infant mortality rate of 72/1000; an under-five mortality rate of $112 / 1000$; and a maternal mortality rate estimated to be $800 / 100,000$ [18] [19], but there are wide zonal differences with the highest in the north-east zone. The numerous problems confronting the health sector in Nigeria would remain unresolved unless and until proper attention is given to the issues of adequate funding and management [20] [21].

Several health care financing systems have been utilized ranging from out of pockets expenditures, employer finance mechanisms, general tax revenues, charitable or voluntary organizations, community based health care financing methods, and recently social health insurance schemes [22]. Despite all these strategies, access to health care in Nigeria is still far below the global standards [23] [24] [25] [26]. Nigeria's National Health Insurance was established to ensure health insurance coverage for the general population, but less than $10 \%$ people have registered and most of them are employer based [14] [27].

Willingness to pay determination is increasingly assuming a key role in decision making and policy formulation, and this is especially true in the valuation of benefits, modelling of demand and the design and implementation of user fees for a variety of services and good [28].

Although, the scheme has formally taken off in the federation, how much of this innovative scheme does the Nigeria populace know? How ready are the health facilities for this scheme? Is the scheme viable within the Nigerian socio-cultural context? These are some of the vital questions begging for answers that informed the choice of this study. Other questions include the influence of economic factors and health status in the utilization of the scheme. The result of this study will help the policy makers to achieve more success for the scheme.

\section{Methods}

The study was conducted among heads of households and health workers in Enugu East Local Government Area (LGA), of Enugu State. One of the thirty six states in Nigeria, Enugu is the capital of old eastern region and of current Enugu state in southeast, Nigeria, with a population of 722,644 people. Seventeen local government areas make up the state while the Enugu metropolis comprises of three local government areas: Enugu east, Enugu south and Enugu north. The Enugu east LGA headquarters is at Nkwo Nike which has six health districts: Abakpa-Nike, Trans-Ekulu, Emene, Mbulujodo, Mbuluoweghe and Mbuluiyiukwu. Three of the districts are rural, while the remaining three are urban. The LGA has 12 health centres/health posts, a comprehensive 
health centre and 65 private owned hospitals, clinics and maternities which are registered with the Enugu state ministry of health. The people in the LGA are mostly Igbos, but people of other ethnic groups such as Yoruba, Hausa, Ijaw and Isoko also reside in the LGA. Majority are traders, civil servants, and artisans. English and Igbo languages are commonly spoken by the people [6].

In this study area, a cross sectional survey was carried out, using multi-stage sampling technique to select the sample studied. Simple random sampling was used to select one urban and one rural district from the sample frame of six districts in Enugu East LGA. Two political wards were selected by simple random sampling (balloting) from each of the districts. Ten Streets were selected by simple random sampling (balloting) from the districts. Finally, 400 heads of households were selected by systematic sampling. All 43 health workers in health facilities in the two districts selected were included in the study.

The justification for the study area was that the LGA has rural and urban districts, while heads of households are mostly responsible for the medical expenses incurred, so their perception and willingness to pay is very important for the success of the scheme. Also, health workers knowledge and health system readiness to participate is crucial for accessibility.

Ten trained interviewers administered the questionnaires which had been translated to the local Igbo language. Data collected was analysed using SPSS Statistical software version 20, and statistical significance of association between variables was assessed using Chi-square test at $\mathrm{p}<0.05$. Ethical approval was obtained from Health Research Ethics Committee of University of Nigeria Teaching Hospital, Enugu. Permission was obtained from the chairman of Enugu East LGA, while verbal and written consent was obtained from the head of households and the health workers respectively.

The sample size was determined by use of the statistical formula $n=\frac{Z^{2} P(1-P)}{d^{2}}$

$d=$ minimum sample size, $Z=$ standard normal deviate set at $95 \%$ confidence interval (1.96), $P^{22}=$ proportion in the target population estimated from a previous study on willingness to participate in the NHIS according to the study done in Ilorin, Kwara state, Nigeria was $66.1 \%, d=$ degree of accuracy which is $0.05, q=1-p$

$$
\begin{aligned}
q & =1-0.66, \\
n & =\frac{1.96^{2} \times 0.66 \times 0.34}{0.05^{2}} \\
& =\frac{3.8416 \times 0.2244}{0.0025}
\end{aligned}
$$

$n=3.44$. The minimum sample size was equal to 344 approximately, but the sample size was increased to 400 to make room for non-response.

The sample size (43) for health workers included all health workers in all the health facilities in the selected districts in Enugu East LGA that registered with the State Ministry of Health.

Questionnaire used for heads of households captured information on awareness, 
perception, willingness to pay and how much they are willing to pay for the scheme, while those for health workers included awareness, and readiness to participate in the scheme.

Perception of the participants on NHIS was assessed using a questionnaire comprising of 15 questions and categorized as: correct (12 or more correct answers), wrong (3 or fewer correct answers).

Definition of variables: Government workers in this study referred to the civil servants and military, while non-government workers are traders, farmers, artisans, and others. Head of household is either the husband, wife, or the most senior adult in the house during the period of the study. All the health workers in the health facilities represent the facilities in this study.

\section{Results}

\subsection{Socio-Demographic Characteristics of the Study Participants}

A total of 400 heads of households participated in the study. Majority of them were males 255 (63.8\%), and the mean age was $36.3 \pm 11.6$ years. Majority of the respondents were between ages of $30-49$ years (53.6\%). Among the respondents, three hundred and three $(75.8 \%)$ were married, while only 60 (15\%) had tertiary education. Most of the respondents were self-employed 279 (69.7\%) (Table 1).

\subsection{Awareness and Sources of Information on NHIS}

Table 2 reveals that majority of the participants $56.8 \%$ are aware of NHIS, and the sources of information are radio $109(48 \%)$, television 32 (14.1\%), newspaper 20 (8.8\%), seminar $4(1.8 \%)$, and others $62(27.3 \%)$.

\subsection{Awareness, Perception and Willingness to Pay According to Level of Education of Respondents}

Table 3 shows that awareness increased significantly with increasing level of education from $37.5 \%$ at no formal education to $58.5 \%, 58.8 \%$, and $70.3 \%$ at primary, secondary, and tertiary educational levels respectively $\left(\mathrm{X}^{2}=16.083, \mathrm{df}=3, \mathrm{p}=0.00\right)$.

Those that had correct perception among the respondents were 239 (59.8\%), while those with wrong perception were $161(40.2 \%)$. The perception on NHIS improved significantly with increasing educational levels from $47.2 \%$ at no formal education to $54.1 \%, 65.4 \%$, and $70.3 \%$ at primary, secondary and tertiary educational levels respectively $\left(\mathrm{X}^{2}=11.167, \mathrm{df}=3, \mathrm{p}=0.01\right)$.

Most of the participants 356 (89\%) are willing to pay for NHIS, but only 175 (43.8\%) were willing to pay mandatory $5 \%$ premium of their earnings. Willingness to pay for NHIS according to levels of education was not statistically significant $\left(\mathrm{X}^{2}=1.274, \mathrm{df}=\right.$ $3, \mathrm{p}=0.64)$.

\subsection{Awareness, Perception and Willingness to Pay According to Occupation of Respondents}

Table 4 shows that awareness among those respondents who are Government employed 
Table 1. Socio-demographic characteristics of the respondents.

\begin{tabular}{|c|c|c|}
\hline Demographic Characteristics & Frequency & Percent \\
\hline \multicolumn{3}{|l|}{ Sex: } \\
\hline Male & 255 & 63.8 \\
\hline Female & 145 & 36.2 \\
\hline \multicolumn{3}{|l|}{ Age Group (Years): } \\
\hline $20-29$ & 37 & 9.2 \\
\hline $30-39$ & 105 & 26.3 \\
\hline $40-49$ & 109 & 27.3 \\
\hline $50-59$ & 73 & 18.2 \\
\hline $60-69$ & 52 & 13.0 \\
\hline $70-79$ & 24 & 6.0 \\
\hline \multicolumn{3}{|l|}{ Marital Status: } \\
\hline Married & 303 & 75.8 \\
\hline Widowed & 54 & 13.5 \\
\hline Separated & 26 & 6.5 \\
\hline Divorced & 17 & 4.2 \\
\hline \multicolumn{3}{|l|}{ Educational Qualification: } \\
\hline None & 73 & 18.2 \\
\hline Primary & 112 & 28.0 \\
\hline secondary & 155 & 38.8 \\
\hline Tertiary & 60 & 15.0 \\
\hline \multicolumn{3}{|l|}{ Religion: } \\
\hline Christian & 361 & 90.3 \\
\hline Muslim & 10 & 2.5 \\
\hline African Traditional Religion & 4 & 1.0 \\
\hline Other religions & 25 & 6.2 \\
\hline \multicolumn{3}{|l|}{ Occupation: } \\
\hline Government employed & 121 & 30.3 \\
\hline Self employed & 279 & 69.7 \\
\hline
\end{tabular}

Table 2. Awareness and sources of information on NHIS.

\begin{tabular}{lcc}
\hline & Frequency & Percentage \\
\hline Awareness: & 227 & 56.8 \\
Yes & 173 & 43.2 \\
No & & \\
Sources of Information: & 109 & 48.0 \\
Radio & 32 & 14.1 \\
Television & 20 & 8.8 \\
Newspaper & 4 & 1.8 \\
Seminar & 62 & 27.3 \\
Others & &
\end{tabular}


Table 3. Awareness, perception and willingness to pay according to level of education of respondents.

\begin{tabular}{|c|c|c|c|c|c|c|c|}
\hline \multirow{4}{*}{ Level of Education } & \multicolumn{7}{|c|}{ Awareness of NHIS } \\
\hline & $\mathrm{N}$ & \multirow{2}{*}{\multicolumn{2}{|c|}{ Yes }} & \multirow{2}{*}{\multicolumn{2}{|c|}{ No }} & \multirow{3}{*}{$\chi^{2}$} & \multirow{3}{*}{$\mathrm{P}$} \\
\hline & & & & & & & \\
\hline & & $\mathrm{N}$ & $\%$ & $\mathrm{~N}$ & $\%$ & & \\
\hline None & 72 & 27 & 37.5 & 45 & 62.5 & & \\
\hline Primary & 111 & 65 & 58.5 & 46 & 41.5 & 16.083 & 0.001 \\
\hline Secondary & 153 & 90 & 58.8 & 63 & 41.2 & & \\
\hline \multirow[t]{5}{*}{ Tertiary } & 64 & 45 & 70.3 & 19 & 29.7 & & \\
\hline & \multicolumn{7}{|c|}{ Perception of NHIS } \\
\hline & \multicolumn{7}{|l|}{$\mathrm{N}$} \\
\hline & & \multicolumn{2}{|c|}{ Correct } & \multicolumn{2}{|c|}{ Not Correct } & & \\
\hline & & $\mathrm{N}$ & $\%$ & $\mathrm{~N}$ & $\%$ & & \\
\hline None & 72 & 34 & 47.2 & 38 & 52.8 & & \\
\hline Primary & 111 & 60 & 54.1 & 51 & 45.9 & 11.167 & 0.011 \\
\hline Secondary & 153 & 100 & 65.4 & 53 & 34.6 & & \\
\hline \multirow[t]{5}{*}{ Tertiary } & 64 & 45 & 70.3 & 19 & 29.7 & & \\
\hline & \multicolumn{7}{|c|}{ Willingness to pay for NHIS } \\
\hline & \multicolumn{7}{|l|}{$\mathrm{N}$} \\
\hline & & \multicolumn{2}{|c|}{ Yes } & \multicolumn{2}{|c|}{ No } & & \\
\hline & & $\mathrm{N}$ & $\%$ & $\mathrm{~N}$ & $\%$ & & \\
\hline None & 72 & 41 & 56.9 & 31 & 43.1 & & \\
\hline Primary & 111 & 55 & 49.5 & 56 & 50.5 & 1.274 & 0.642 \\
\hline Secondary & 153 & 97 & 63.4 & 56 & 36.6 & & \\
\hline Tertiary & 64 & 51 & 79.7 & 13 & 20.3 & & \\
\hline
\end{tabular}

Table 4. Awareness, perception and willingness to pay according to occupation of respondents.

\begin{tabular}{|c|c|c|c|c|c|c|c|}
\hline \multirow{4}{*}{ Occupation } & \multicolumn{7}{|c|}{ Awareness of NHIS } \\
\hline & $\mathrm{N}$ & & & \multirow{2}{*}{\multicolumn{2}{|c|}{ No }} & \multirow{3}{*}{$\chi^{2}$} & \multirow{3}{*}{$\mathrm{P}$} \\
\hline & & \multicolumn{2}{|c|}{ Yes } & & & & \\
\hline & & $\mathrm{N}$ & $\%$ & $\mathrm{~N}$ & $\%$ & & \\
\hline Government Employed & 121 & 81 & 66.9 & 40 & 33.1 & 5.694 & 0.017 \\
\hline \multirow[t]{5}{*}{ Non-Government Employed } & 279 & 151 & 54.1 & 128 & 45.9 & & \\
\hline & \multicolumn{7}{|c|}{ Perception of NHIS } \\
\hline & \multirow[t]{3}{*}{$\mathrm{N}$} & & & & & & \\
\hline & & \multicolumn{2}{|c|}{ Correct } & \multicolumn{2}{|c|}{ Not Correct } & & \\
\hline & & $\mathrm{N}$ & $\%$ & $\mathrm{~N}$ & $\%$ & & \\
\hline Government Employed & 121 & 86 & 71.1 & 35 & 28.9 & 4.243 & 0.672 \\
\hline \multirow[t]{5}{*}{ Non-Government Employed } & 279 & 126 & 45.2 & 153 & 54.8 & & 2.078 \\
\hline & \multicolumn{7}{|c|}{ Willingness to pay for NHIS } \\
\hline & $\mathrm{N}$ & & & & & & \\
\hline & & \multicolumn{2}{|c|}{ Yes } & \multicolumn{2}{|c|}{ No } & & \\
\hline & & $\mathrm{N}$ & $\%$ & $\mathrm{~N}$ & $\%$ & & \\
\hline Government Employed & 121 & 113 & 93.4 & 8 & 6.6 & 5.169 & 0.023 \\
\hline Non-Government Employed & 279 & 239 & 85.7 & 40 & 14.3 & & \\
\hline
\end{tabular}


(66.9\%) are significantly more than those that are not employed by Government (54.1\%). More Government employed respondents $71.1 \%$ had correct perception of NHIS than non-Government respondents $45.2 \%$, but not statistically significant $\left(\mathrm{X}^{2}=\right.$ $4.243, \mathrm{df}=1, \mathrm{P}=0.67$ ). Willingness to pay for NHIS was significantly more among the Government employed $93.4 \%$ than non-Government employed $85.7 \%\left(\mathrm{X}^{2}=5.169, \mathrm{df}=\right.$ $1, \mathrm{P}=0.02)$.

\subsection{Awareness, Perception and Willingness to Pay According to Sex of Respondents}

Table 5 shows that awareness is more among males $57.3 \%$ compare to females $51.7 \%$, but the difference was not statistically significant $\left(\mathrm{X}^{2}=0.437, \mathrm{df}=1, \mathrm{P}=0.64\right)$. Also, greater proportion of males $61.1 \%$, had correct perception than females $58.6 \%$. Those who are willing to pay for NHIS are more among males $90.6 \%$ than females $86.2 \%$. The differences observed in perception and willingness to pay among the respondents according to sex are not statistically significant respectively $\left(\mathrm{X}^{2}=0.336, \mathrm{df}=1, \mathrm{P}=0.56\right.$, $\left.\mathrm{X}^{2}=1.813, \mathrm{df}=1, \mathrm{P}=0.18\right)$.

\subsection{Preferred Mode of Payment for Health Care Services}

Most respondents $61 \%$ preferred government alone to pay for healthcare services while $12.2 \%$ preferred payment through insurance. Only $6.5 \%$ wanted payment for healthcare services from pocket (Table 6).

Table 5. Awareness, perception and willingness to pay according to sex of the respondents.

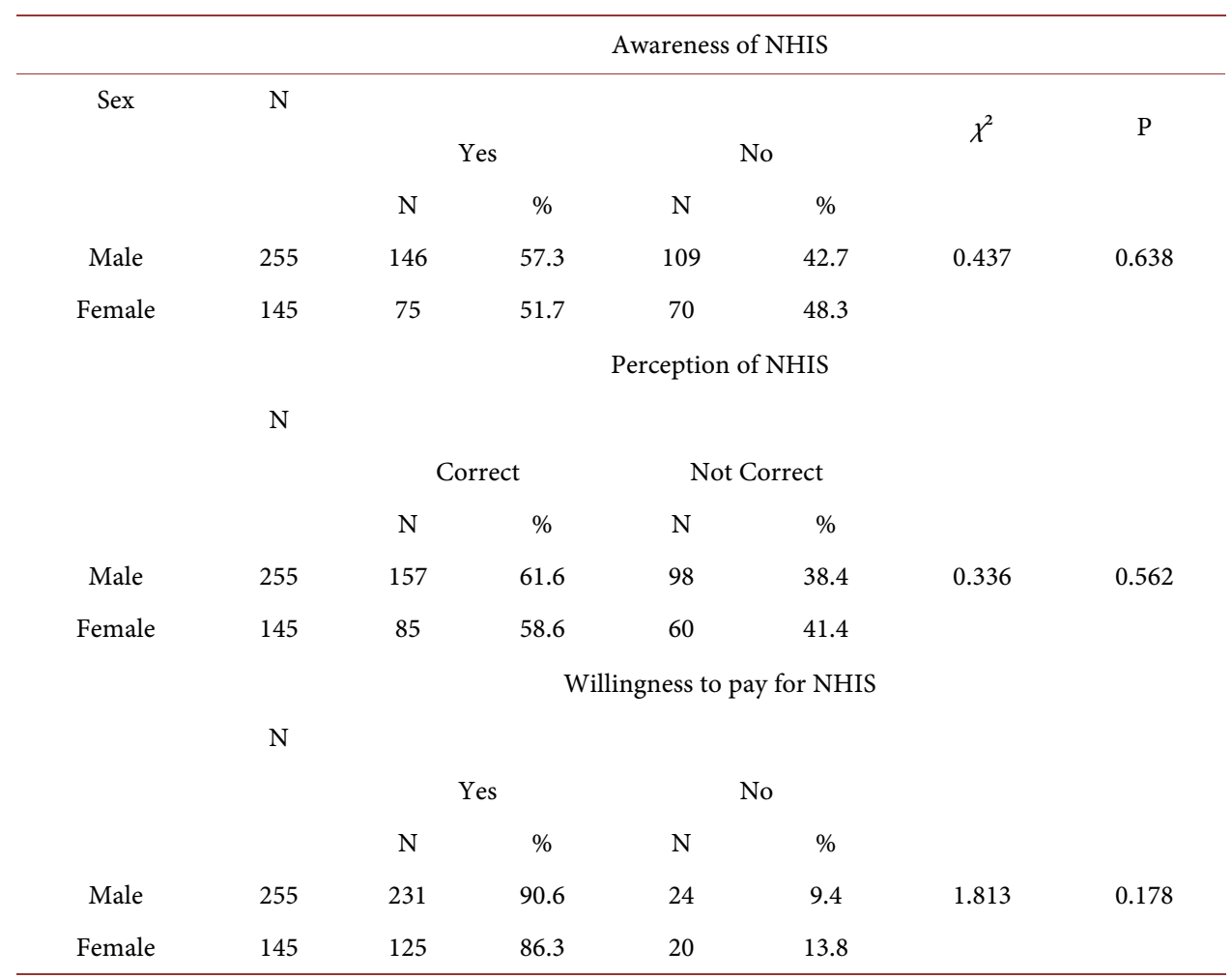




\subsection{Percentage of Earnings Willing to Pay for NHIS by the Participants}

Table 7 reveals that majority of respondents $89 \%$ are willing to pay for NHIS, but only $43.8 \%$ are willing to pay mandatory $5 \%$ premium of the salary. Fourty-four (11\%) participants are not willing to pay any amount as premium, One hundred and one (45.2\%) are willing to pay between $(1 \%-4 \%)$, while no one is willing to pay above $5 \%$ of their earning.

\subsection{Health Sector Readiness for NHIS}

Table 8 reveals that awareness among health workers was high $86 \%$, but only $34.9 \%$ of the health workers interviewed believed that the health sector system are ready for the scheme. Also, only $11.6 \%$ of the health facilities have been enlisted for the scheme

Table 6. Preferred mode of payment for health care services.

\begin{tabular}{lcc}
\hline & Frequency N $=400$ & Percent \\
\hline From pocket only: & 26 & 6.5 \\
Yes & 374 & 93.5 \\
No & & \\
By government only: & 244 & 61.0 \\
Yes & 156 & 39.0 \\
No & & \\
Through insurance: & 49 & 12.2 \\
Yes & 351 & 87.8 \\
No & & 7.2 \\
By voluntary organization: & 29 & 92.8 \\
Yes & 371 & \\
No & & \\
\hline
\end{tabular}

Table 7. Percentage of earnings willing to pay by the participants.

\begin{tabular}{lcc}
\hline & Frequency $\mathbf{N}=\mathbf{4 0 0}$ & Percent (\%) \\
\hline Willing to pay: & 356 & 89.0 \\
Yes & 44 & 11.0 \\
No & & \\
Willing to pay mandatory 5\% premium of salary: & 175 & 43.8 \\
Yes & 225 & 56.2 \\
No & & \\
Percentage of earnings willing to pay: & 44 & 11 \\
0 & 35 & 8.8 \\
1 & 26 & 6.5 \\
2 & 100 & 25.0 \\
3 & 20 & 4.9 \\
4 & 175 & 43.8 \\
5 & 0 & 0
\end{tabular}


Table 8. Health sector readiness for NHIS.

\begin{tabular}{|c|c|c|}
\hline Variables & Frequency $\mathrm{N}=43$ & Percent \\
\hline \multicolumn{3}{|l|}{ Awareness: } \\
\hline Yes & 37 & 86.0 \\
\hline No & 6 & 14.0 \\
\hline \multicolumn{3}{|l|}{ Hospital readiness: } \\
\hline Yes & 15 & 34.9 \\
\hline No & 28 & 65.1 \\
\hline \multicolumn{3}{|l|}{ Training on health insurance: } \\
\hline Yes & 9 & 20.9 \\
\hline No & 34 & 79.1 \\
\hline \multicolumn{3}{|l|}{ Hospital enlistment for NHIS: } \\
\hline Yes & 5 & 11.6 \\
\hline No & 38 & 88.4 \\
\hline \multicolumn{3}{|l|}{ Know any HMO: } \\
\hline Yes & 5 & 11.6 \\
\hline No & 38 & 88.4 \\
\hline \multicolumn{3}{|l|}{ Knowledgeable on health insurance: } \\
\hline Yes & 13 & 30.2 \\
\hline No & 30 & 69.8 \\
\hline \multicolumn{3}{|l|}{ Providers mobilization: } \\
\hline Yes & 14 & 32.6 \\
\hline No & 29 & 67.4 \\
\hline \multicolumn{3}{|c|}{ Willing to undertake a course on NHIS: } \\
\hline Yes & 34 & 79.1 \\
\hline No & 9 & 20.9 \\
\hline \multicolumn{3}{|l|}{ Willingness to participate: } \\
\hline Yes & 40 & 93.0 \\
\hline No & 3 & 7.0 \\
\hline
\end{tabular}

among the hospitals in the study area. About $69.8 \%$ of the respondents believed that they are not knowledgeable on health insurance, while only $32.6 \%$ said providers' mobilization is enough for NHIS. Most respondents $93 \%$ are willing to participate in the NHIS.

\section{Discussion}

Majority of households were headed by males $63.8 \%$. This is similar to the study done in Osun State, South-West, Nigeria [29], but different from the study carried out in an 
urban south Indian population where $61.6 \%$ of respondents were females [30]. Also, majority of the participants are in their productive age (30 - 50 years) in both studies. The awareness of NHIS in this study is above average $56.8 \%$. This level of awareness is greater than the study done in 2012 [19], but less than the studies done in Northern Nigeria and Southern India where awareness was $98.7 \%$ and $64 \%$ respectively [30] [31] [32]. However, our result is similar to the findings in the studies done in Cross-River and Kogi States [33] [34]. This difference in level of awareness could be as a result of the fact that our study was done about two years after the NHIS started in Nigeria. The studies done in Ilorin and in South-East, Nigeria on awareness and attitude of medical practitioners towards NHIS revealed 100\% awareness of the scheme [35] [36]. The difference with this study might be because all the categories of health workers were participants in our study unlike the studies in Ilorin and South-East that involved only medical doctors and radiographers respectively. Also, in this study, most respondents major sources of information among the heads of households are Radio and Television, but in the study done among medical practitioners, their major source of information are newspapers, while seminars in the hospitals were noted to be major source of information among radiographers [35] [36]. This could be due to differences in the literacy level. Among the respondents, only $44 \%$ of them felt that they have adequate information, while $24.3 \%$ felt that people are adequately mobilized about the scheme. The study is similar to the one conducted in Ilorin that revealed that the level of information and mobilization of the public is still inadequate for the scheme. This is unpleasant observation as adequate information and mobilization of both public and healthcare providers is very essential for acceptability.

The perception about the NHIS in the LGA is encouraging as $55.5 \%$ believed that health insurance is a way of paying for healthcare services, $77.8 \%$ believed everybody can be health insured and 77\% believed that NHIS will work in Nigeria. From this study, more than average of the respondents had correct perception of NHIS, and this is influenced by the level of education. This could be that more people got the information from the print media. Our findings on perception are similar to the results on the studies conducted in Southern Nigeria and South Africa [29] [31] [36] [37]. In our study, awareness and perception of NHIS was significantly higher among the respondents that are government employed compared to those not employed by government. This difference could be due to the fact that the scheme has commenced fully among federal civil servants in the country.

Our findings in this study revealed about $89 \%$ of the respondents among heads of households are willing to pay for the NHIS, but only $43.8 \%$ of the respondents are willing to pay mandatory $5 \%$ premium of their earnings. This result is different from the study conducted in South Africa where only 39\% of the population was willing to take health insurance [37]. Levels of education, sex, and occupation of respondents affected willingness to pay in this study. Though, premium on our study was based on percentage of their earnings, the result is similar to studies done on willingness to pay for private voluntary health insurance scheme in South-East, Nigeria, and willingness to pay 
for community health insurance and its determinants among household heads in rural communities in North-Central Nigeria, India South Africa [28] [30] [37] [38] [39] [40]. It was found out that more male $90.6 \%$ are willing to pay for the scheme than female $86.2 \%$. Most of the respondents $95.9 \%$ from this study are willing to pay $1 \%-3 \%$ premium of their earnings, while no respondent is willing to pay above $5 \%$ of their earnings. Our findings are significant for the policy makers of NHIS for good coverage and implementation because most respondents are not willing to pay $5 \%$ of their earnings as premium as presently stipulated. The findings in this study have shown that the scheme is viable within the Nigerian socio-cultural context, but more studies should be done on the health needs and utilization.

Most respondents among heads of households $96 \%$ preferred liberalization of the benefit package unlike as it is presently packaged. This finding is different from the study conducted in Ilorin where only $43.9 \%$ of them accepted NHIS as presently packaged. About $57 \%$ of the respondents actually wanted the contribution rate determined by the benefit package selected. This finding about the benefit package is important for the policy makers of the scheme for proper planning and successful implementation. Sex and education levels of the respondents did not influence the benefit package preference as most of them preferred liberalization of the package.

In our study, most of the respondents among the healthcare workers $93 \%$ are willing to participate in NHIS. This is similar to the study done in Ghana on willingness to participate and pay for the health insurance where over $90 \%$ of the respondents agreed to participate in the scheme [41], but it is different from the study conducted in Ilorin where only $66.1 \%$ are willing to participate [35]. The difference might be due to the fact the actual implementation has commenced and now more health workers are willing to participate in the scheme because of adequate attention on the scheme presently by the government. The study also revealed that only $11.6 \%$ of the health facilities have been enlisted for the scheme among the hospitals in the study area, but $34.9 \%$ of the health workers believed that the health sector system are ready for the scheme. The health facilities enlisted is not adequate for the coverage, but this might be due to fear of prompt payment for the services.

\section{Conclusions and Recommendations}

Majority of the participants in this study had good perception of the scheme and are willing to pay, but the level of awareness was not satisfactory. However, the proportion of the health facilities enlisted for the scheme is not adequate for proper coverage. More efforts should be made to improve on the awareness creation programmes for the public, and the monthly premium should also be reviewed to be within the value that majority of households will be able to afford. The scheme should enlist more private facilities for good coverage.

\section{Acknowledgements}

We acknowledged the sponsor of this study, Alliance for Health Policy and System Re- 
search/WHO, and Health Research Group of University of Nigeria that facilitated the sponsorship. The authors would like to show appreciation to heads of households, and health care workers that participated in the study. We also thank the field staff that collected the data for their commitment.

\section{Conflict of Interest}

The authors declare that there is no conflict of interests regarding the publication of this paper.

\section{References}

[1] Xu, K., Evans, D., Carrin, G. and Aguilar-Rivera, A.M. (2005) Designing Health Financing Systems to Reduce Catastophic Health Expenditure. Technical Briefs for Policy-Makers. WHO/EIP/HSF/PB/05.02. WHO, Geneva.

[2] Abel-Smith, B. (1991) Financing Health for All. World Health Forum, 12, 191-200.

[3] Ernst, S., Judith, M., Noor, T., et al. (2012) The Impact of Health Insurance in Africa and Asia: A Systemic Review. Bulletin of the World Health Organization, 90, 685-692. http://dx.doi.org/10.2471/BLT.12.102301

[4] Blancher, N.J. and Osei-Akoto, I. (2012) The Effect of Ghana's National Health Insurance on Health Care Utilization. Ghana Medical Journal, 46, 76-84.

[5] WHO (2010) World Health Report 2010-Health Systems Financing: The Path to Universal Coverage. World Health Organization, Geneva.

[6] All Africa Global Media; KPMG Africa Limited (2012) The State of Healthcare in Africa.

[7] Sidua, H. (2013) Ten Years and Major Pitfalls Still Hindering Ghana's National Health Insurance Scheme. Ghana Medical Journal, 6-7.

[8] August, K. and Josephine, B. (2012) Health Insurance Scheme in Tanzania. Ifakara Health Institute, 11, 1-4.

[9] O'Connell, T. (2012) National Health Insurance in Asia and Africa: Advancing Equitable Social Health Protection to Achieve Universal Health Coverage. UNICEF, New York.

[10] Morestin, F. and Ridde, V. (2009) How Can the Poor Be Better Integrated into Health Insurance Programs in Africa? An Overview of Possible Strategies. Universite de Montreal, Canada, 1-5.

[11] Edozien, F.V. (1996) The National Health Insurance Scheme: The Alternative Funding System for the Health Sector. Nigerian Journal of Health Planning Management, 2, 24-26.

[12] Aghayere, V.O. (2002) Managing Human and Financial Resources for Health for All in Nigeria. Institute of Public Administration and Extension Services, University of Benin Edo State, Nigeria, 79-90.

[13] Onyia, J.C. (2001) National Health Insurance Ascheme: Essential Information for Medical Laboratory Scientists. Labnews, 10-12.

[14] Lawumi, A. (2015) Health Insurance in Nigeria. Medical World Nigeria, 1-5.

[15] Mohammed, D.M. Expanding Health Insurance Coverage in Nigeria.

[16] Federal Ministry of Health (2015) Nigeria's National Health Insurance Scheme: Recruiting Achievements.

[17] Alausa, O.K. and Osibogun, A. (1995) Health Care Financing in a Depressed EconomyOptions for Nigeria. Journal of Community Medicine and Primary Health Care, 7, 18- 34. 
[18] UNICEF (2015) Monitoring Situation of Children and Women.

[19] Uzochukwu, B.S.C. and Onwuzurike, B.K. (2001) Knowledge, Attitude and Practice of Family Planning amongst Women in a High Density Low Income of Enugu, Nigeria. Africa Journal of Reproductive Health, 5, 83-89. http://dx.doi.org/10.2307/3583433

[20] Federal Ministry of Health (1996) National Health Policy. Abuja.

[21] Smith, B.A. (1992) Health Insurance in Developing Countries: Lessons from Experience. Health Policy and Plannning, 7, 215-226. http://dx.doi.org/10.1093/heapol/7.3.215

[22] Mach, A. and Abel-Smith, B. (1983) Planning the Finances of the Health Sector: A Manual for Developing Countries. World Health Organization, Geneva.

[23] Katibi, I.A., Akande, A.A. and Akande, T.M. (2003) Awareness and Attitude of Medical Practitioners in Ilorin towards National Health Insurance Scheme. Nigerian Medical Practitioner, 43, 33-35. http://dx.doi.org/10.4314/smj2.v6i1.12819

[24] FGN-UNICEF (2001) Children's Rights in Nigeria: Challenges of a Better Legacy-A Situation Assessment and Analysis.

[25] Operational Guidelines of National Health Insurance Scheme (2005) 7-14.

[26] Airede, L.R. (2003) Implementing the National Health Insurance Scheme: the dawn of a new in health care financing in Nigeria. Sahel Medical Journal, 6, 1-5. http://dx.doi.org/10.4314/smj2.v6i1.12816

[27] National Population Commission (2014) Nigeria Demographic and Health Survey. Abuja, 50-51.

[28] Onwujekwe, O.E. and Velenyi, E.V. (2012) Willingness to Pay for Private Voluntary Health Insurance in South-East, Nigeria. Afican Journal of Health Economics, 1, 109-112.

[29] Abayomi, S.O. (2012) Factors Influencing Households' Willingness to Pay for National Health Insurance Scheme in Osun State, Nigeria. Studies on Ethno-Medicine, 6, 167-172.

[30] Bhageerathy, R., Nair, N.S., Sabu, K.M. and Unnikrishnan, B. (2012) Awareness, Attitude and Their Correlates towards Health Insurance in an Urban South Indian Population. Management in Health, 16, 32-35.

[31] Owu, E., Ifatimehin, O.O. and Shaka, S. (2014) Assessment of the Level of Awareness of the Effectiveness of National Health Insurance Scheme among Workers in Kaduna Metropolis, Nigeria. Journal of Education and Policy Review, 6, 43-51

[32] Bhageerathy, R., Nair, N.S., Sabu, K.M. and Unnikrishnan, B. (2007) Awarenes of Health Insurance in a South Indian Population-A Community Based Study. Health and Population-Perspectives and Issues, 30, 177-188.

[33] Agba, A.M., Ushie, E.M. and Osuchukwu, N.C. (2010) National Health Insurance Scheme and Employees Access to Healthcare Services in Cross River State, Nigeria. Global Journal of Human Social, 10, 56-67.

[34] Agba, M.S. (2010) Perceived Impact of National Health Insurance Scheme among Registered Staff in Federal Polytechnic Idah Kogi State, Nigeria. Studies in Sociology of Science, $1,44-49$.

[35] Onwujekwe, O.E., Uzochukwu, B.S., Ezeoke, O.P. and Uguru, N.P. (2011) Health Insurance: Principles, Models and the Nigerian National Health Insurance Scheme. International Journal of Medicine and Health Development, 16, 45-54

[36] Okaro, A.O., Ohagwu, C.C. and Njoku, J. (2010) Awareness and Perception of National Health Insurance Scheme among Radiographers in South East Nigeria. American Journal of Scientific Research, 2, 18-25.

[37] Olive, S., Thomas, R., Julia, L., Nompumelelo, Z.D., Pelisa, D. and Laetitia, R. (2006) Public 
Perception on National Health Insurance: Moving towards Universal Health Coverage in South Africa. South African Medical Journal, 96, 814-818.

[38] Onwujekwe, O.E., Okereke, E., Onoka, C., Uzochukwu, B.S.C., Kirigia, J. and Petu, A. (2010) Willingness to Pay for Community-Based Health Insurance in Nigeria: Do Economic Status and Place of Residence Matter? Health Policy and Planning, 25, 155-161. http://dx.doi.org/10.1093/heapol/czp046

[39] Babatunde, O.A., Akande, T.M., Salaudeen, A.G., Aderibigbe, S.A., Elegbede, O.E. and Ayodele, L.M. (2012) Willingness to Pay for Community Health Insurance and Its Determinants among Household Heads in Rural Communities in North-Central, Nigeria. International Review of Social Sciences and Humanities, 2, 133-142.

[40] Owumi, B.E., Adeoti, A.B. and Patricia, A.T. (2013) National Health Insurance Scheme Dispensing Outreach and Maintenance of Health Status in Oyo State. International Journal of Humanities and Social Science Invention, 2, 37-46.

[41] Asenso, O.W.K., Osei, A.I. and Anum, A. (1997) Willingness to Pay for Health Insurance in a Developing Economy. A Pilot Study of the Informal Sector of Ghana Using Contingent Evaluation. Health Policy, 42, 223-237. http://dx.doi.org/10.1016/S0168-8510(97)00069-9

\section{Abbreviations}

NHIS: National Health Insurance Scheme

LGA: Local Government Area

HMO: Health Maintenance Organization

HCP: Health Care Provider for you:

Accepting pre-submission inquiries through Email, Facebook, LinkedIn, Twitter, etc. A wide selection of journals (inclusive of 9 subjects, more than 200 journals)

Providing 24-hour high-quality service

User-friendly online submission system

Fair and swift peer-review system

Efficient typesetting and proofreading procedure

Display of the result of downloads and visits, as well as the number of cited articles

Maximum dissemination of your research work

Submit your manuscript at: http://papersubmission.scirp.org/

Or contact health@scirp.org 